\title{
Proximate, Amino Acid, Fatty Acid, Vitamins and Mineral analysis of Catfish, Arius maculatus and Plotosuslineatus from Parangipettai South East Coast ofIndia.
}

\author{
T.Manikandarajan*, A.Eswar, R.Anbarasu, K.Ramamoorthy and G.Sankar \\ Centre of Advanced Study in Marine Biology, Faculty of Marine Science, Annamalai University, Parangipettai - \\ 608 502, Tamil Nadu, India. \\ Corresponding author: T.Manikandarajan, Research scholar, Centre of AdvancedStudy in Marine Biology, \\ Faculty of Marine Science,Annamalai University, Parangipettai-608 502, Tamil Nadu,India,
}

\begin{abstract}
In general the proximate composition is known as percentage composition of basic component such as water, protein, lipids, carbohydrate and minerals. The catfishArius maculatus and Plotosus lineatuswere separated into two parts: head and body.The head and body region of A.maculatus and P.lineatus having (24.93gm, $21.82 \mathrm{gm}),(2.15 \mathrm{gm}, 0.92 \mathrm{gm}),(59.36 \mathrm{gm}, 43.07 \mathrm{gm}),(4.42 \mathrm{gm}, 3.98 \mathrm{gm}),(5.17 \mathrm{gm}, 3.01 \mathrm{gm}),(42.17$ $\mathrm{gm}, 32.56 \mathrm{gm}),(2.79 \mathrm{gm}, 1.98 \mathrm{gm}),(65.04 \mathrm{gm}, 66.93 \mathrm{gm}),(10.97 \mathrm{gm}, 3.46 \mathrm{gm})$ and $(7.26 \mathrm{gm}, 4.03 \mathrm{gm} / 100 \mathrm{~g})$ respectively.Totally nineteen amino acids observed in the both spotted catfish and striped eel catfish. The phenylalanine, lysine and valine are the main elements based on the quantum of availability of essential amino acids (EAA) in the head and body portion of catfish.The palmitic acid $(0.655,0.792 \mathrm{mg}$ and $0.735,0.944 \mathrm{mg})$ is the predominant fatty acid observed in head and body. Seven vitamins were found in the both catfish samples. They are Vitamin A, C, D, E, B6, B1 and Vitamin B12. Vitamin E (4.28 mg, $7.52 \mathrm{mg})(3.28 \mathrm{mg}, 5,45 \mathrm{mg})$ is the predominant vitamin in head and body. Seven minerals were observed in both catfish sample like Ca, $\mathrm{Mg}, \mathrm{Zn}$, $\mathrm{Fe}, \mathrm{Cu}, \mathrm{Na}$ and $\mathrm{K}$. Ca (108.4mg, 165.2mg), Zn (146mg, 5.45mg), Na (138.2mg, 164.8mg) are the predominant elementsin head and body region of catfish. This study exposed that this catfish species are able to struggle with more commercially utilize species in terms of nutritional value, and they can definitely also compete when it comes to taste.
\end{abstract}

Keywords:Amino acids, Arius maculatus, Fattyacid, Mineral, Plotosus lineatus.

\section{Introduction}

In world wide the nutritional quality of food is much more important. The nutritional consequence of marine food has increased widely because of the beneficial effects of eating marine food fats and oils [1]. Marine food is also one of the most important sources of high-protein and highly digestible protein and a superior source of essential minerals [2]. In general the fish has a standard valuable source of elevated value of protein in the human diet. In recent years, fish fats have also assumed huge nutritional significance due to their protective role against the development of cardiovascular disease and rheumatoid arthritis [3].

In general the proximate composition is known as percentage composition of basic component such as water, protein, lipids,carbohydrate and minerals. The energy yielding nutrients like protein, carbohydrate and fats are asmacronutrients present in anelevatedlevel where as non energy yielding nutrients like vitamins and minerals areconsidered as micronutrients are present in small amounts[4].Fish are known as to be one of the cheapest sources of animalprotein and other essential nutrients required in human diets [5].In recent years, fish lipids have also assumed great nutritional significance owing to their protective role against the development of cardiovascular disease and rheumatoid arthritis [6].

Althoughdetermining of the proximate composition and mineral elements of Catfish (Arius maculates(Thunberg, 1792) and Plotosus lineatus (Thunberg, 1787) are havinganenormousvalues due to the good quality effect on human health. This Catfish are also having a good source of various minerals. Therefore, it is so essential to human health,from these minerals, Calcium $(\mathrm{Ca})$ and Irons $(\mathrm{Fe})$ are necessary to maintain an optimal bone development, more of bothminerals being required during childhood and growing stages to prevent rickets and Osteomalacia [7]. Calcium has an essential role inchemical transmitter release, blood clotting, muscle contraction and normal heartbeat. Fe is an essential formany proteins and enzymes that maintain good health; transporting oxygen in the blood to all parts of thebody as well as proper functioning of the liver [8].Zinc (Zn) is a constituent of many enzymes and is essential for the proper function of these various enzymes. $\mathrm{Zn}$ is essential for the metabolism and structural stability of nucleic acids. $\mathrm{Zn}$ has been connected with a variety of bodily functions such as the wound healing, reproduction, growth and maintenance of glucose tolerance in the body[9]. A.maculates and P.lineatus are commonly known as in the name of spotted catfishand 
striped eel catfish. This catfishare generally edible and has a significant commercial value in the aquarium industries. [10], [11].

The Objective of the work was planned to study the proximate composition of A. maculatus and P.lineatus through estimating their major biochemical components such as total protein, carbohydrate, lipid, amino acids, fatty acid profile, vitamins and mineral content on head and body parts.

\section{Materials and Methods}

The catfish were purchased in Mudasal odai landing center, Parangipettai(Lat.11 $29^{\prime} \mathrm{N}$; Long. $\left.79^{\circ} 46^{\prime} \mathrm{E}\right)$ in the month of February, 2014 and transported immediately to the laboratory for the analysis. The catfish were separated into two parts:which is head and body. The digestive system was removed and edible portion only took for the analysis.Each species of the fish sample was oven-dried in an electric oven at between $70-80^{\circ} \mathrm{C}$ until the samples had constant weight and used following procedure for the analysis.

2.1. Estimation of Carbohydrate:

The total carbohydrate level was estimated by phenol- sulphuric acid method of Dubois et al.,[12].

\subsection{Estimation of Protein}

The Folin-Ciocalteu Phenol method of Lowry et al., was used for the estimation of total protein content in the catfish [13].

\subsection{Estimation of Lipid:}

The total lipid content was estimated gravimetrically by following Folch et al., [14].

\subsection{Estimation of amino acids:}

The experimental samples were finely grounded for estimating the amino acids in the HPLC (Merck Hitachi L-7400) following the method of Baker, et al., [15].

\subsection{Fatty acid analysis:}

For fatty acid analysis, the samples were homogenized with chloroform: methanol $(2: 1 \mathrm{v} / \mathrm{v})$ mixture and they were extracted using the method of Bligh et al., [16]. After the fat extraction, they were esterifies with $1 \% \mathrm{H} 2 \mathrm{So} 4$ and fatty acid methyl esters were prepared by following the procedure of AOAC(1995).The identification and quantification of fatty acids were done using Gas Chromatography (Hewlett Packard 5890 model) [17].

\subsection{Estimation of vitamins:}

The fat soluble vitamins $\mathrm{A}, \mathrm{D}, \mathrm{E}$ and $\mathrm{K}$ and the water soluble vitamins B1, B6, B12 and C were analyzed in the HPLC (Merk Hitachi L-74000) following the method described by Sadasivam and Manickam [18].The folic acid was estimated by following the calorimetric procedure of Sethi, 1997. The pyridoxine, panthothenic acid were estimated by following methods are suggested in USP NF 2000 Asian edition [19].

\subsection{Estimation of minerals:}

The minerals were estimated by following the method of Guzman and Jimenez [20].

\subsection{Proximate composition:}

\section{Result}

In this present study the protein, carbohydrate, fat, ash and moisture content of spotted catfish(A.maculatus) and striped eel catfish (P.lineatus) were investigated. The head and body region of A.maculatus and P.lineatushaving $(24.93 \mathrm{gm}, 21.82 \mathrm{gm}),(2.15 \mathrm{gm}, 0.92 \mathrm{gm}),(59.36 \mathrm{gm}, 43.07 \mathrm{gm}),(4.42 \mathrm{gm}, 3.98$ $\mathrm{gm}),(5.17 \mathrm{gm}, 3.01 \mathrm{gm}),(42.17 \mathrm{gm}, 32.56 \mathrm{gm}),(2.79 \mathrm{gm}, 1.98 \mathrm{gm}),(65.04 \mathrm{gm}, 66.93 \mathrm{gm}),(10.97 \mathrm{gm}, 3.46 \mathrm{gm})$ and (7.26 gm,4.03 gm)respectively. A.maculatus contains a high content of protein, carbohydrate,fat, ash and moisture than P.lineatus.Table 1 and fig.1 shows the proximate composition of Catfish A. maculatus and P. lineatus

Table1: Proximate composition of A.maculatus and P.lineatusfor gm/100gm. 
Proximate, Amino Acid, Fatty Acid, Vitamins and Mineral analysis of Catfish, Arius maculatus ...

\begin{tabular}{|l|l|r|r|r|r|}
\hline \multirow{2}{*}{ S.No: } & & \multicolumn{2}{|c|}{$\begin{array}{l}\text { Arius maculatus } \\
\text { (Head) }\end{array}$} & \multicolumn{2}{c|}{$\begin{array}{l}\text { Plotosus lineatus } \\
\text { (Bead)(Body) }\end{array}$} \\
\hline 1 & Protein & $24.93 \mathrm{gm}$ & $42.17 \mathrm{gm}$ & $21.82 \mathrm{gm}$ & $32.56 \mathrm{gm}$ \\
\hline 2 & Carbohydrate & $2.15 \mathrm{gm}$ & $2.79 \mathrm{gm}$ & $0.92 \mathrm{gm}$ & $1.98 \mathrm{gm}$ \\
\hline 3 & Fat & $59.36 \mathrm{gm}$ & $65.04 \mathrm{gm}$ & $43.07 \mathrm{gm}$ & $66.93 \mathrm{gm}$ \\
\hline 4 & Ash & $4.42 \mathrm{gm}$ & $10.97 \mathrm{gm}$ & $3.98 \mathrm{gm}$ & $3.46 \mathrm{gm}$ \\
\hline 5 & Moisture & $5.17 \mathrm{gm}$ & $7.26 \mathrm{gm}$ & $3.01 \mathrm{gm}$ & $4.03 \mathrm{gm}$ \\
\hline
\end{tabular}

Figure 1: Proximate composition of A.maculatus and P. lineatus for gm/100gm.

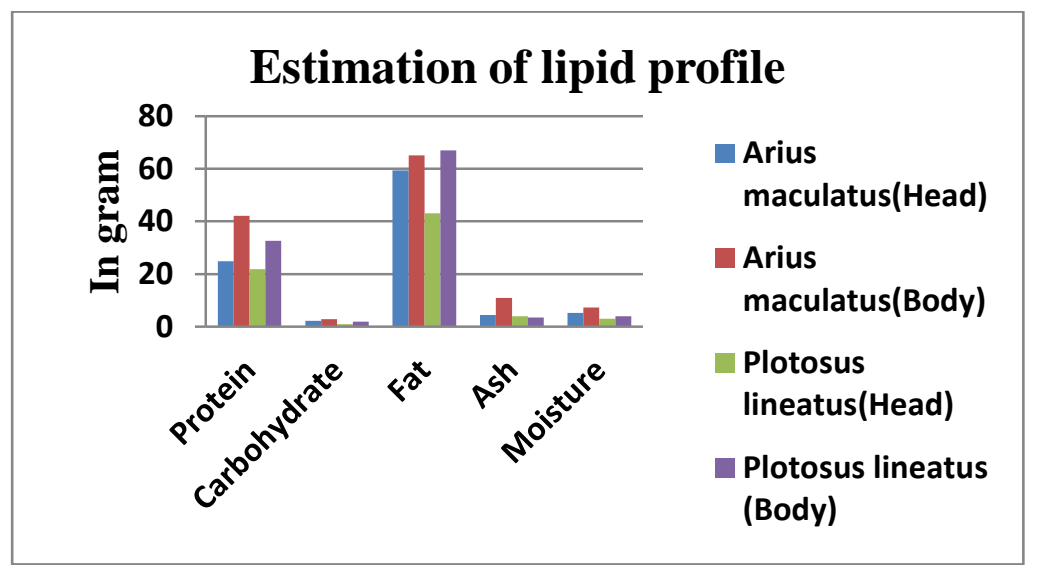

3.2. Estimation ofamino acid:

The present investigation shows totally nineteen amino acids present in the both spotted catfish and striped eel catfish. The phenylalanine, lysine and valine are the main elements based on the quantum of availability of essential amino acids (EAA) in the head and body portion of catfish. Therefore,Threonine $(0.196 \mathrm{gm}, 0.684 \mathrm{gm})$, Arginine $(0.372 \mathrm{gm}, 0.829 \mathrm{gm})$, Histidine $(0.426 \mathrm{gm}, 0.973 \mathrm{gm})$, Valine, $(0.992 \mathrm{gm}, \quad 1.203 \mathrm{gm}) \quad$ Methionine $(0.203 \mathrm{gm}, \quad 0.985 \mathrm{gm})$, Isoleucine $(1.098 \mathrm{gm}, \quad 1.021$ $\mathrm{gm})$, Phenylanine,(1.174 gm, $1.046 \mathrm{gm})$ Leucine (1.146 gm, $1.013 \mathrm{gm})$, Lysine $(0.427 \mathrm{gm}, 0.982 \mathrm{gm})$ and Tryptophan $(0.425 \mathrm{gm}, 0.976 \mathrm{gm})$ are the EAA observed in head and body part of A.maculatus. The essential amino acid contents have listed in Table 2. Threonine (0.092gm, $0.119 \mathrm{gm})$, Arginine (0.103gm, 0.291gm), Histidine $(0.174 \mathrm{gm}, 0.353 \mathrm{gm})$, Valine, $(0.389 \mathrm{gm}, 0.893 \mathrm{gm})$ Methionine $(0.125 \mathrm{gm}, 0.156 \mathrm{gm})$, Isoleucine (0.453 gm, $0.923 \mathrm{gm})$, Phenylanine,(0.501 gm, $0.993 \mathrm{gm})$ Leucine $(0.498 \mathrm{gm}, 0.981 \mathrm{gm})$, Lysine $(0.176 \mathrm{gm}$, $0.356 \mathrm{gm})$ and Tryptophan $(0.172 \mathrm{gm}, 0.353 \mathrm{gm})$ are the major NEAA in head and body part of P.lineatus. Significant variations in amino acids content were observed between head and body part of the spotted and striped eel catfish. The NEAA contents are shows in Table No: 3.The result revealed in this study shows that, the catfishA.maculatus and P.lineatus meat having an average potential source of balanced essential amino acids. The results were measured by fig. 4 standard graph.

Table2: Estimation of essential amino acid of A.maculatus and P.lineatus for gm/100gm.

\begin{tabular}{|c|c|c|c|c|c|}
\hline \multirow{2}{*}{$\begin{array}{c}\text { S.No } \\
1 \\
\end{array}$} & \multirow{2}{*}{$\begin{array}{c}\begin{array}{c}\text { Essential Amino } \\
\text { Acids }\end{array} \\
\text { Threonine } \\
\end{array}$} & \multicolumn{2}{|c|}{$\begin{array}{l}\text { Arius maculatus } \\
\text { (Head) (Body) }\end{array}$} & \multicolumn{2}{|c|}{$\begin{array}{l}\text { Plotosus lineatus } \\
\text { (Head) (Body) }\end{array}$} \\
\hline & & $0.196 \mathrm{gm}$ & $0.684 \mathrm{gm}$ & $0.092 \mathrm{gm}$ & $0.119 \mathrm{gm}$ \\
\hline 2 & Arginine & $0.372 \mathrm{gm}$ & $0.829 \mathrm{gm}$ & $0.103 \mathrm{gm}$ & $0.291 \mathrm{gm}$ \\
\hline 3 & Histidine & $0.426 \mathrm{gm}$ & $0.973 \mathrm{gm}$ & $0.174 \mathrm{gm}$ & $0.353 \mathrm{gm}$ \\
\hline 4 & Valine & $0.992 \mathrm{gm}$ & $1.203 \mathrm{gm}$ & $0.389 \mathrm{gm}$ & $0.893 \mathrm{gm}$ \\
\hline 5 & Methionine & $0.203 \mathrm{gm}$ & $0.985 \mathrm{gm}$ & $0.125 \mathrm{gm}$ & $0.156 \mathrm{gm}$ \\
\hline 6 & IsoLeucine & $1.098 \mathrm{gm}$ & $1.021 \mathrm{gm}$ & $0.453 \mathrm{gm}$ & $0.923 \mathrm{gm}$ \\
\hline 7 & Phenylanine & $1.174 \mathrm{gm}$ & $1.046 \mathrm{gm}$ & $0.501 \mathrm{gm}$ & $0.993 \mathrm{gm}$ \\
\hline 8 & Leucine & $1.146 \mathrm{gm}$ & $1.013 \mathrm{gm}$ & $0.498 \mathrm{gm}$ & $0.981 \mathrm{gm}$ \\
\hline 9 & Lysine & $0.427 \mathrm{gm}$ & $0.982 \mathrm{gm}$ & $0.176 \mathrm{gm}$ & $0.356 \mathrm{gm}$ \\
\hline 10 & Tryptophan & $0.425 \mathrm{gm}$ & $0.976 \mathrm{~m}$ & $0.172 \mathrm{gm}$ & $0.353 \mathrm{gm}$ \\
\hline
\end{tabular}

Figure 2: Estimation of essential amino acid of A.maculatus and P. lineatus for gm/100gm. 


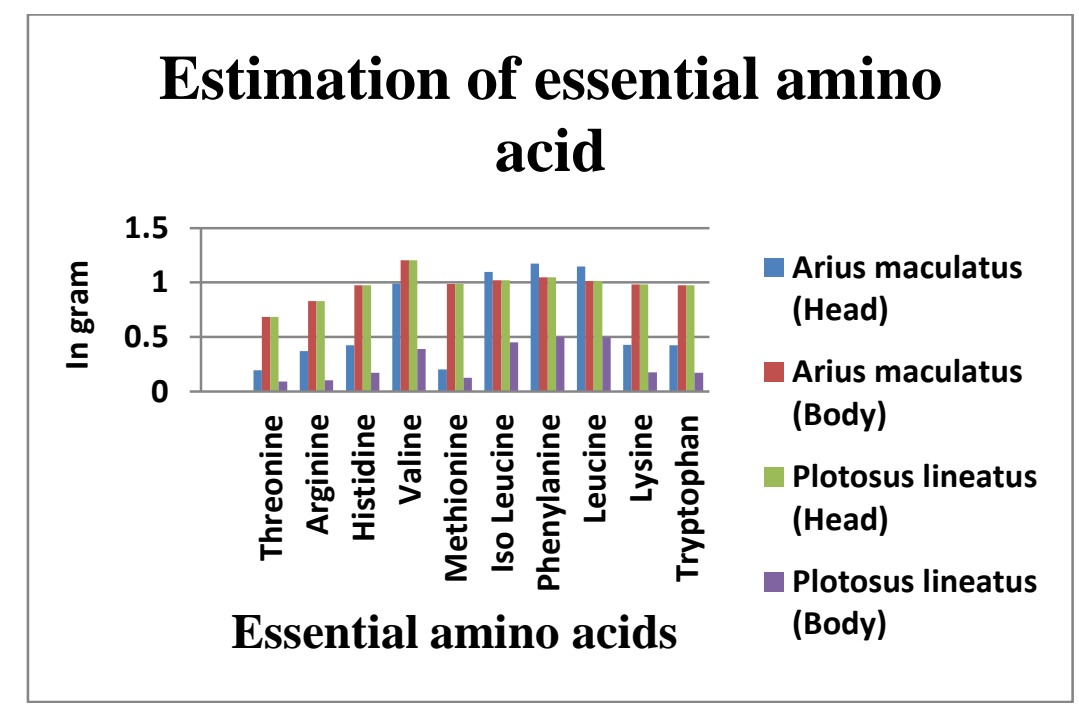

Table3: Estimation of non-essential amino acid of A.maculatus and P.lineatus for gm/100gm.

\begin{tabular}{|c|l|r|r|r|r|}
\hline S.No & $\begin{array}{l}\text { Non-essential } \\
\text { Amino Acids }\end{array}$ & \multicolumn{2}{|l|}{$\begin{array}{l}\text { Arius maculatus } \\
\text { (Head)(Body) }\end{array}$} & \multicolumn{2}{l|}{$\begin{array}{l}\text { Plotosus lineatus } \\
\text { (Head) (Body) }\end{array}$} \\
\hline & & $1.303 \mathrm{gm}$ & $0.426 \mathrm{gm}$ & $0.174 \mathrm{gm}$ & $0.353 \mathrm{gm}$ \\
\hline 1 & Aspartic Acid & $0.407 \mathrm{gm}$ & $1.013 \mathrm{gm}$ & $0.368 \mathrm{gm}$ & $0.834 \mathrm{gm}$ \\
\hline 2 & Glutamic Acid & $0.109 \mathrm{gm}$ & $0.847 \mathrm{gm}$ & $0.186 \mathrm{gm}$ & $0.293 \mathrm{gm}$ \\
\hline 3 & Asparagine & $0.215 \mathrm{gm}$ & $0.572 \mathrm{gm}$ & $0.089 \mathrm{gm}$ & $0.115 \mathrm{gm}$ \\
\hline 4 & Serine & $0.136 \mathrm{gm}$ & $0.692 \mathrm{gm}$ & $0.214 \mathrm{gm}$ & $0.343 \mathrm{gm}$ \\
\hline 5 & Glycine & $0.312 \mathrm{gm}$ & $0.992 \mathrm{gm}$ & $0.391 \mathrm{gm}$ & $0.834 \mathrm{gm}$ \\
\hline 6 & Alanine & $0.101 \mathrm{gm}$ & $0.398 \mathrm{gm}$ & $0.119 \mathrm{gm}$ & $0.334 \mathrm{gm}$ \\
\hline 7 & Cysteine & $0.380 \mathrm{gm}$ & $0.751 \mathrm{gm}$ & $0.216 \mathrm{gm}$ & $0.565 \mathrm{gm}$ \\
\hline 8 & Tyrosine & $0.096 \mathrm{gm}$ & $0.358 \mathrm{gm}$ & $0.107 \mathrm{gm}$ & $0.291 \mathrm{gm}$ \\
\hline 9 & Proline & & &
\end{tabular}

Figure 3: Estimation of non-essential amino acid of A.maculatus and P. lineatus for gm/100gm.

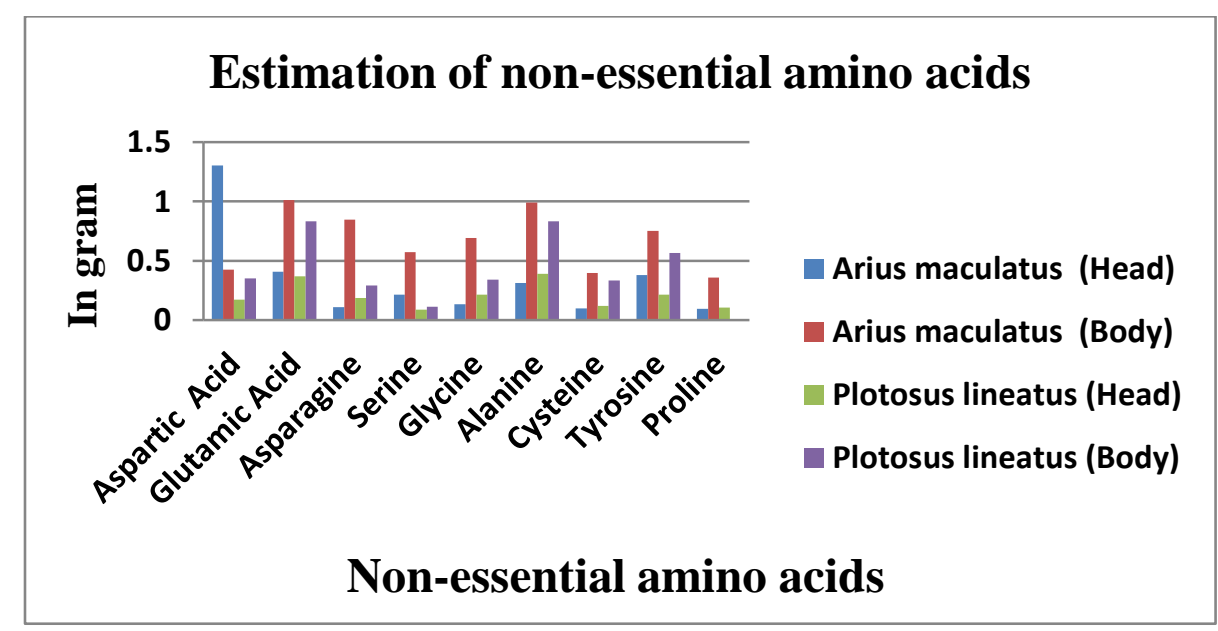


Figure 4: Standard graph for amino acid

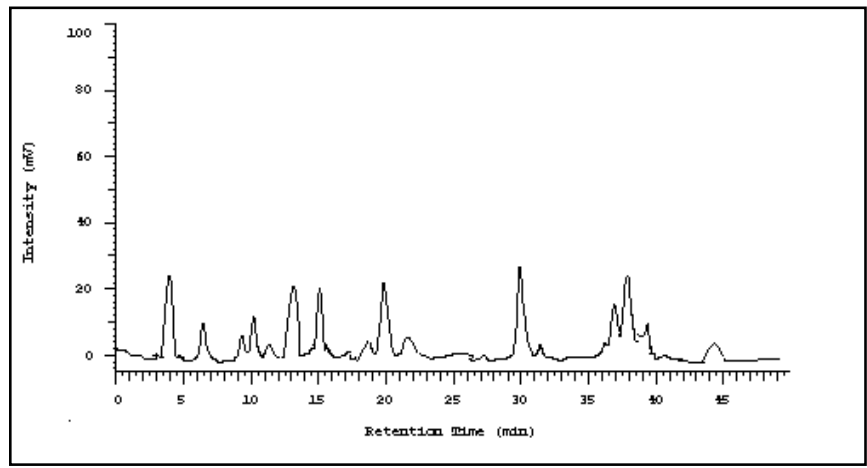

\subsection{Estimation of Fatty acids:}

In this present study six major fatty acids were observed like Palmitic acid, Stearic acid 18:0, Oleic acid 18:1, Linolenicacids, Alpha Linolenic acid and Moroctic acid 18:4 detected in the both catfish samples. The fatty acid concentrations of the catfish are listed in Table 4. Therefore, Palmitic acid $(6.55 \mathrm{gm}, 7.92 \mathrm{gm})$, Alpha Linolenic acid $(3.43 \mathrm{gm}, 7.17 \mathrm{gm})$ Stearic acid $(2.96 \mathrm{gm}, 6.55 \mathrm{gm})$ are the predominant content in head and body part of A.maculatus. Palmitic acid (7.35gm, 9.44gm), Alpha Linolenic acid (4.69gm, 6.36gm) and Oleic acid $(3.83 \mathrm{gm}, 4.91 \mathrm{gm})$. Fatty acid content of A.maculatus has much increased then P.lineatus. The estimation of fatty acid contents have listed in table No 4.The total fatty acid content was measured by fig.6 standard graph.

Table4: Estimation of fatty acid of A.maculatus and P.lineatus for gm/100gm.

\begin{tabular}{|c|c|c|c|c|c|}
\hline \multirow{2}{*}{$\begin{array}{r}\text { S.No } \\
1 \\
\end{array}$} & \multirow{2}{*}{$\begin{array}{l}\text { Fatty Acids } \\
\text { Palmitic Acid }\end{array}$} & \multicolumn{2}{|c|}{$\begin{array}{l}\text { Arius maculatus } \\
\text { (Head) (Body) }\end{array}$} & \multicolumn{2}{|c|}{$\begin{array}{l}\text { Plotosus lineatus } \\
\text { (Head) (Body) }\end{array}$} \\
\hline & & $6.55 \mathrm{gm}$ & $7.92 \mathrm{gm}$ & $7.35 \mathrm{gm}$ & $9.44 \mathrm{gm}$ \\
\hline 2 & Stearic Acid 18:0 & $2.96 \mathrm{gm}$ & $6.55 \mathrm{gm}$ & $3.01 \mathrm{gm}$ & $4.05 \mathrm{gm}$ \\
\hline 3 & Oleic Acid 18:1 & $3.20 \mathrm{gm}$ & $5.42 \mathrm{gm}$ & $3.83 \mathrm{gm}$ & $4.91 \mathrm{gm}$ \\
\hline 4 & Linolenic Acids & $3.06 \mathrm{gm}$ & $5.95 \mathrm{gm}$ & $3.82 \mathrm{gm}$ & $4.15 \mathrm{gm}$ \\
\hline 5 & Alpha Linolenic Acid & $3.43 \mathrm{gm}$ & $7.17 \mathrm{gm}$ & $4.69 \mathrm{gm}$ & $6.36 \mathrm{gm}$ \\
\hline 6 & Morotic Acid 18:4 & $0.55 \mathrm{gm}$ & $0.80 \mathrm{gm}$ & $0.35 \mathrm{gm}$ & $0.93 \mathrm{gm}$ \\
\hline
\end{tabular}

Figure 5: Estimation of fatty acid of A. maculatus and P. lineatus for gm/100gm.

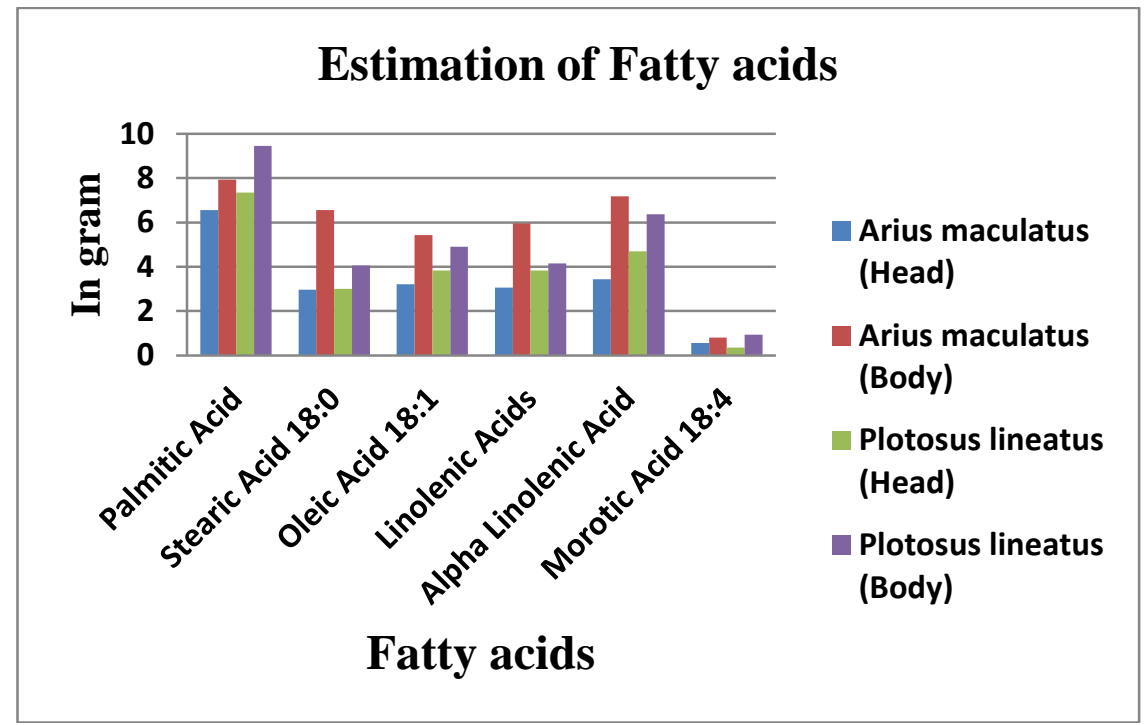

Figure 6: Standard graph for Fatty acid

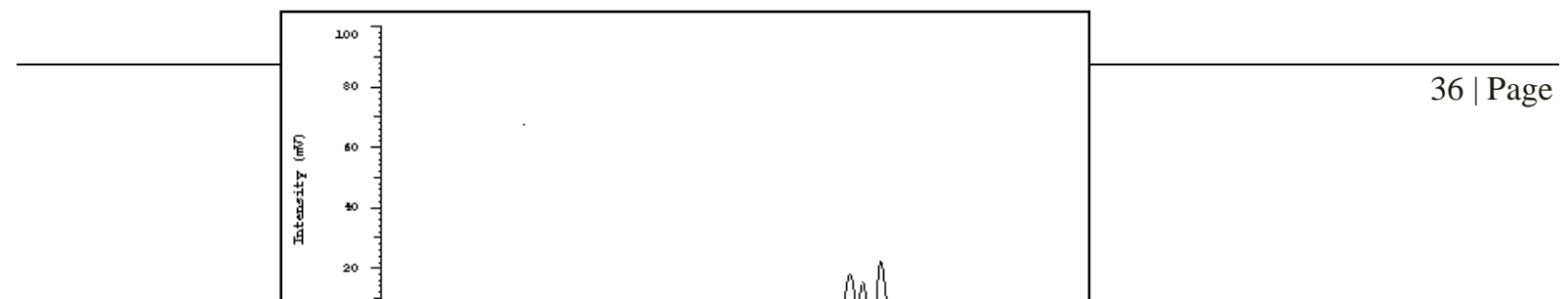


3.4. Estimation of Vitamins:

In this current investigation totally 7 vitamins are observed in both catfish samples. They are Vitamin A, C, D, E, B6, B1 and Vitamin B12.Vitamin A is measured by in an international unit.Vitamin A (15.210 IU, (21.68 IU),Vitamin D (2.16mg, $3.04 \mathrm{mg})$, Vitamin E (4.28 mg, $7.52 \mathrm{mg})$, Vitamin B6 (1.93mg, 3.98mg), Vitamin B12 (0.219mcg, $0.536 \mathrm{mcg})$, Vitamin C $(1.09 \mathrm{mg}, 2.27 \mathrm{mg})$ Vitamin B1 $(1.97 \mathrm{mg}, 3.52 \mathrm{mg})$ are the major vitamins in head and body part of A.maculatus. Vitamin E $(3.28 \mathrm{mg}, 5,45 \mathrm{mg})$, Vitamin D $(1.32 \mathrm{mg}$, $2.11 \mathrm{mg}$ ), and Vitamin B1 (1.06mg, 2.56mg) are highest concentration observed in head and body part of P.lineatus.The vitamins concentrations on the catfish are listed in Table 5.

Table5: Estimation of Vitamins of A. maculatus and P.lineatus for gm/100gm.

\begin{tabular}{|c|c|c|c|c|c|}
\hline \multirow{2}{*}{$\begin{array}{r}\text { S.No } \\
1 \\
\end{array}$} & \multirow{2}{*}{$\begin{array}{l}\text { Vitamins } \\
\text { Vitamin-A } \\
\end{array}$} & \multicolumn{2}{|c|}{$\begin{array}{l}\text { Arius maculatus } \\
\text { (Head) (Body) }\end{array}$} & \multicolumn{2}{|c|}{$\begin{array}{l}\text { Plotosus lineatus } \\
\text { (Head) (Body) }\end{array}$} \\
\hline & & $15.210 \mathrm{IU}$ & $21.68 \mathrm{IU}$ & $11.43 \mathrm{IU}$ & $19.45 \mathrm{IU}$ \\
\hline 2 & Vitamin-D & $2.16 \mathrm{mg}$ & $3.04 \mathrm{mg}$ & $1.32 \mathrm{mg}$ & $2.11 \mathrm{mg}$ \\
\hline 3 & Vitamin-E & $4.28 \mathrm{mg}$ & $7.52 \mathrm{mg}$ & $3.28 \mathrm{mg}$ & $5.45 \mathrm{mg}$ \\
\hline 4 & Vitamin-B6 & $1.93 \mathrm{mg}$ & $3.98 \mathrm{mg}$ & $1.02 \mathrm{mg}$ & $2.45 \mathrm{mg}$ \\
\hline 5 & Vitamin-B12 & $0.219 \mathrm{mcg}$ & $0.536 \mathrm{mcg}$ & $0.124 \mathrm{mcg}$ & $0.334 \mathrm{mcg}$ \\
\hline 6 & Vitamin-C & $1.09 \mathrm{mg}$ & $2.27 \mathrm{mg}$ & $0.93 \mathrm{mg}$ & $1.35 \mathrm{mg}$ \\
\hline 7 & Vitamin-B1 & $1.97 \mathrm{mg}$ & $3.52 \mathrm{mg}$ & $1.06 \mathrm{mg}$ & $2.56 \mathrm{mg}$ \\
\hline
\end{tabular}

Figure 7: Estimation of Vitamins of A. maculatus and P .lineatus for gm/100gm.

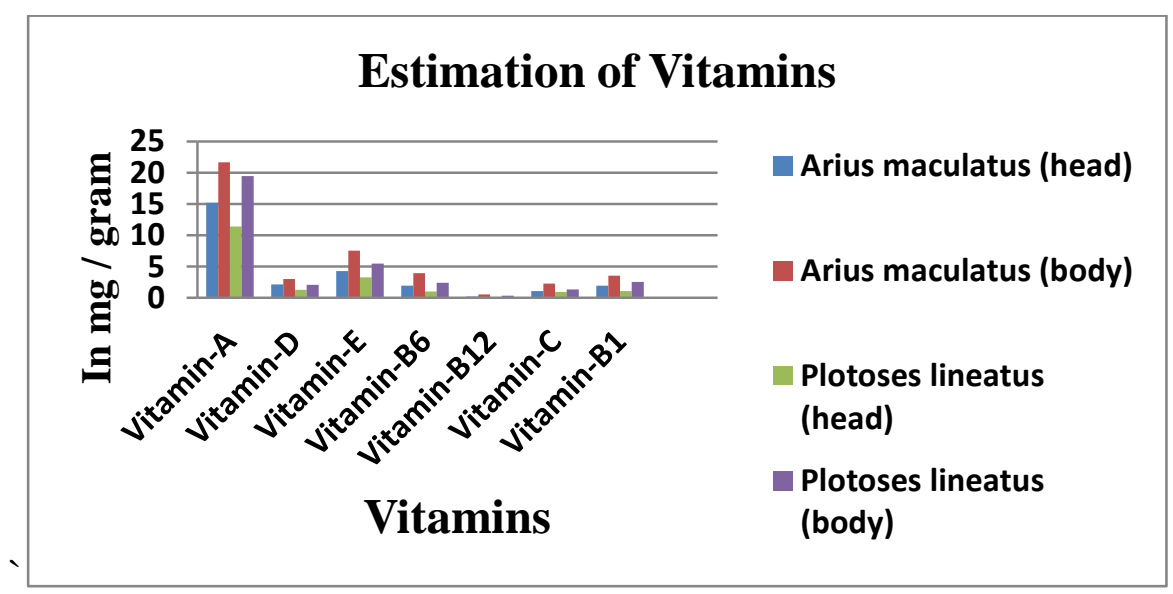

\subsection{Estimation of minerals:}

In this present study totally seven minerals are observed in both catfish sample like Calcium (Ca), Magnesium (Mg), Zinc ( $\mathrm{Zn})$, Iron ( $\mathrm{Fe})$, Copper $(\mathrm{Cu})$, Sodium $(\mathrm{Na})$ and Potassium $(\mathrm{K})$. In the catfish $\mathrm{Zn}$ 
(146mg, 5.45mg), Na (138.2mg, 164.8mg), Ca (108.4mg, 165.2mg), are the predominant minerals in head and body part of A.maculatus. K (106.2mg, 134.6mg), Mg(105.6mg, $124.6 \mathrm{mg})$, Na (112.4mg, 143.6mg) are the predominant minerals in head and body part of P.lineatus. The vitamins concentrations on the catfish are listed in Table 6.

Table6: Estimation of Minerals of A.maculatus and P.lineatus for gm/100gm.

\begin{tabular}{|r|l|r|r|r|r|}
\hline S.No & Minerals & \multicolumn{2}{|l|}{$\begin{array}{l}\text { Arius maculatus } \\
\text { (Head) }\end{array}$} & \multicolumn{2}{l|}{$\begin{array}{l}\text { Plotosus lineatus } \\
\text { (Head) }(\text { Body) }\end{array}$} \\
\hline 1 & Calcium & $108.4 \mathrm{mg}$ & $165.2 \mathrm{mg}$ & $098.1 \mathrm{mg}$ & $135.7 \mathrm{mg}$ \\
\hline 2 & Magnesium & $101.8 \mathrm{mg}$ & $141.4 \mathrm{mg}$ & $105.6 \mathrm{mg}$ & $124.6 \mathrm{mg}$ \\
\hline 3 & Zinc & $146 \mathrm{mg}$ & $5.45 \mathrm{mg}$ & $2.45 \mathrm{mg}$ & $4.67 \mathrm{mg}$ \\
\hline 4 & Iron & $0.91 \mathrm{mg}$ & $1.63 \mathrm{mg}$ & $0.62 \mathrm{mg}$ & $1.34 \mathrm{mg}$ \\
\hline 5 & Copper & $0.318 \mathrm{mg}$ & $0.530 \mathrm{mg}$ & $0.295 \mathrm{mg}$ & $0.335 \mathrm{mg}$ \\
\hline 6 & Sodium & $138.2 \mathrm{mg}$ & $164.5 \mathrm{mg}$ & $112.4 \mathrm{mg}$ & $143.6 \mathrm{mg}$ \\
\hline 7 & Potassium & $124.4 \mathrm{mg}$ & $157.8 \mathrm{mg}$ & $106.2 \mathrm{mg}$ & $134.6 \mathrm{mg}$ \\
\hline
\end{tabular}

Figure 8: Estimation of Vitamins of A. maculatus and P .lineatus for gm/100gm.

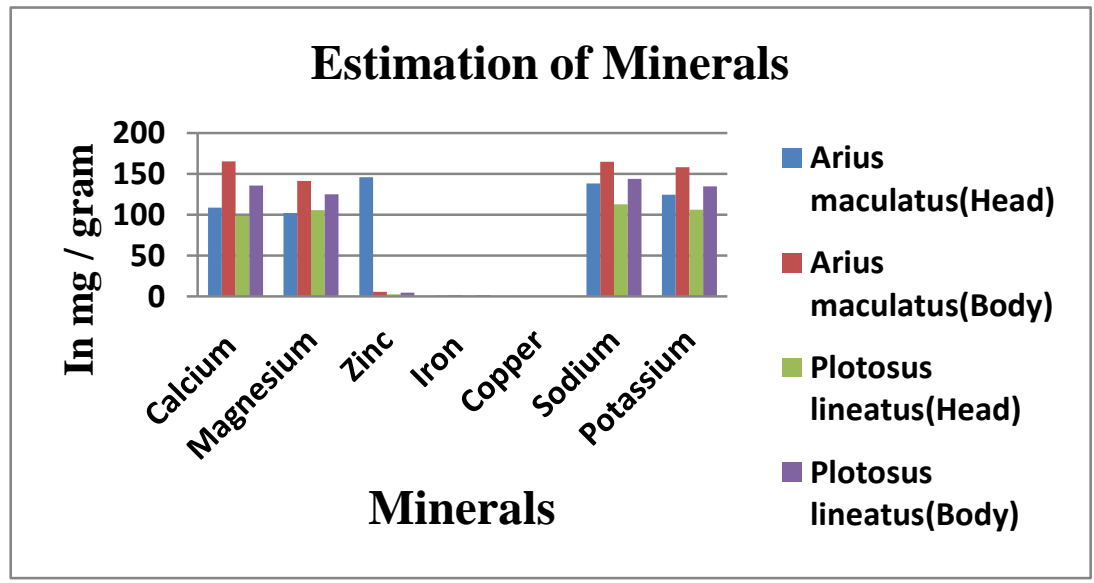

\section{Discussion}

\subsection{Proximate composition:}

In this present analysis the protein contents varied from $21.82 \mathrm{gm}$ and $42.17 \mathrm{gm}$ in the head and body part of marine catfish A.maculatus and P.lineatus (shows in Table 1). Similar works are revealed from various fish species. Vignesh and Srinivasan were studied the protein contents onhead and bone part of Oreochromismossambicus, this fish partshaving 33.59\%-31.52\% respectively [21].These much variance is happened due to the food and feeding patterns of fish in different regions. The dorsal, ventral, lateral line of giant catfishPangasianodongigasshows high level of protein contents than catfishP.lineatus and A.maculatus. This P.gigas has $19.00 \%, 14.36 \%$ and $17.27 \%$ of protein contentson the dorsal, ventral, lateral line region [22].Crude protein content of fish flesh various maybe depending on the species, nutritional conditions of the species, the type of fish species, the state of nutritional level of utilization, and the dynamic cycle of animal as well as the parts of the organism.

The Carbohydrate concentration of A.maculatus and P.lineatus $2.15 \mathrm{gm}, 2.79 \mathrm{gm}, 0.92 \mathrm{gm}$ and $1.98 \mathrm{gm}$ in head and body parts respectively. Several studies were done on various fish.Ogbonnaya and Ibrahim were investigated the carbohydrate level in catfish Clariosgariepinus by drying method. In this catfish the carbohydrate level is5.48, 2.78, and 3.84 percentage in raw, Kiln-dried and electric- dried catfish on head and bone region of O.mossambicushaving $1.45 \%$ and $0.14 \%$ likewise [27].This difference may be different changes at elevated temperature.Fapohunda and Ogunkoya were recorded the carbohydrate concentration in fresh, dried and deteriorating fish sample of Tilapiazillii, ParachannaobscuraandClariasgariepinushas4.72\%, 7.62\%, 
$11.89 \%, 6.93 \%, 6.79 \%, 10.25 \%$ and $16.19 \%, 1.92 \%, 17.35 \%$ in that order [24]. These differences might be due to the geographical location of the water bodies and population of the species.

In this present study fat contents of A.maculatus and P.lineatus showing $59.36 \mathrm{gm}, 65.04 \mathrm{gm}, 43.07 \mathrm{gm}$ and $66.93 \mathrm{gm}$ in head and body parts in that order. Similar studies were conducted on some other fish. ManatChaijan et al were mentioned the fat values are $0.54 \mathrm{~g}$ in dorsal region, $4.21 \mathrm{mg} / \mathrm{g}$ in ventral region, and $8.60 \mathrm{mg} / \mathrm{kg}$ lateral line of P.gigas[22].Holma et al.were observed the fat content in fresh fish, traditionally smoked fish, fried fish and salted red fish had 9.99\%, 10.00\%, 9.67\%, and20.02 respectively[25].

Ash content of the head and body part of marine catfishA.maculatus and P.lineatus have been observed in $4 \mathrm{~m} .42 \mathrm{gm}, 10.97 \mathrm{gm}, 3.98 \mathrm{gm}$ and $3.46 \mathrm{gm} / 100 \mathrm{gm}$ in that order. Several studies were conducted in various fish. The ash contents of O.mossambicushaving $1.14 \%$ on head and $0.89 \%$ on bone region [21].ManatChaijan et al., were mentioned the ash contents are $1.47 \mathrm{~g}$ in dorsal region, $1.13 \mathrm{mg} / \mathrm{g}$ in ventral region, and $1.11 \mathrm{mg} / \mathrm{kg}$ lateral line of P.gigas [22].Holma et al., were observed the ash content in fresh fish, traditionally smoked fish, fried fish and salted red fish had $6.00 \%, 06.07 \%, 30.00 \%$, and 6.00 respectively [25].This dissimilarity might be most probably associated to the size of the species investigated for the separate studies or seasonal conditions at the time of study conducted.

In this present observation the moisture content varied from $5.17 \mathrm{gm}, 7.26 \mathrm{gm}, 3.01 \mathrm{gm}$ and $4.03 \mathrm{gm}$ in the headand body of marine catfish A.maculatus and P.lineatus (Table 1). The moisture contents on head and bone region of O.mossambicushaving 5.89\% and $4.22 \%$ likewise. Vignesh and Srinivasan.,Holma et al, were observed the moisture content in fresh fish, traditionally smoked fish, fried fish and salted red fish had $10.0 \%$, $4.00 \%, 5.90 \%$, and 3.99 respectively [21],[25].ManatChaijan et al. were mentioned the moisture contents are $78.88 \mathrm{~g}$ in dorsal region, $81.67 \mathrm{mg} / \mathrm{g}$ in ventral region, and $75.51 \mathrm{mg} / \mathrm{kg}$ lateral line of P.gigas[22].This elevated moisture contents in an organisms are considered as a benefit, because of its involvement in the stabilization of the organisms during movements

\subsection{Estimation of amino acids:}

The biological value of protein is obviously reflected upon its essential amino acid concentration. In this present study the 19 essential and non essential amino acids are observed. Results are listed in Table 2 and 3. Similar observations are recorded in some other fish species. Vignesh and Srinivasan were recorded 20 essential amino acids contents in O.mossambicus. In this 20 essential amino acid phenyl alanine (1.978\%), aspartic acid (1.837\%), glycine (1.414\%) and asparagines (1.316\%)concentrations arerecorded in the high level on head and bone region of tilapia respectively [21].Kumaran et al. also observed the 10 essential amino acid and 8 non-essential amino acids glutamic acid and aspartic acid (11.06\%) are the pre dominant element found in M.cephalus [26].

\subsection{Estimation of fatty acids:}

In this present study six major fatty acids were observed in catfish. The palmitic acid $(0.655,0.792$ and $0.735,0.944)$ is the predominant fatty acid observed in head andbody part of A.maculatus and P.lineatus (showed in table 4). Similar studies were conducted in various fish. Totally 17 fatty acids were found in P.gigas. The SFA (45.30\%) is the highest concentration in dorsal region of P.gigas [22].Vignesh and Srinivasan, were estimated the fatty acid level alpha linolenic acid $(\mathrm{C} 18: 4)(2.4390 \mathrm{mg} / 100 \mathrm{~g})$ in head region and Stearic acid (C18:0) $(0.7860 \mathrm{mg} / 100 \mathrm{~g})$ in bone region is the predominant elements in O.mossambicus [21].This dissimilarity may be almost certainly connected to the size of the fish species investigated for the separate studies or seasonal conditions at the time of study conducted.

\subsection{Estimation of Vitamins:}

In this present investigation totally 7 vitamins are found in both catfish samples. They are Vitamin A, C, D, E, B6, B1 and Vitamin B12. Vitamin E $(4.28 \mathrm{mg}, 7.52 \mathrm{mg})(3.28 \mathrm{mg}, 5,45 \mathrm{mg})$ is the predominant vitamin in head and bodyof A.maculatus, P.lineatus. Similar works are done by some other fish. Vignesh and Srinivasanwere studied the total vitamin contents vitamin A $(145.60 \mathrm{mg} / \mathrm{g})$, Vitamin C $(45.65 \mathrm{mg} / \mathrm{g})$ is the highest concentration in head and bone region of O.mossambicusrespectively [21].Catfish have more vitamin content than Oreochromisnilotieus(Vitamin A $0.00025 \%$, 0.00046\%, 0.00084\%, Vitamin C $0.0023 \mathrm{mg} / \mathrm{g}$, $0.0040 \mathrm{mg} / \mathrm{g}, 0.0023 \mathrm{mg} / \mathrm{g}$.) in raw, kiln-dried and electric-dried fish sample [23].

\subsection{Estimation of minerals:}

In general the Sea foods are abundant source of mineral components.In this present observation totally seven minerals are observed in both catfish sample like $\mathrm{Ca}, \mathrm{Mg}, \mathrm{Zn}, \mathrm{Fe}, \mathrm{Cu}, \mathrm{Na}$ and $\mathrm{K} . \mathrm{Ca}(108.4 \mathrm{mg}, 165.2 \mathrm{mg}$ ), $\mathrm{Zn}$ (146mg, 5.45mg), Na (138.2mg, 164.8mg) are predominant elementsin head and body region of catfish.Vignesh and Srinivasan were observed the minerals concentration the Calcium $56.7 \%, 67.76 \%$ and Sodium $34.67 \%, 29.11 \%$ are the predominant minerals in head and bone region of O.mossambicus[21].The 
Mugilcephalusflesh has rich quantity of $\mathrm{Na}(68 \mathrm{mg} / 100 \mathrm{~g}) \mathrm{Ca}(48 \mathrm{mg} / 100 \mathrm{~g})$ and $\mathrm{Mg}(28 \mathrm{mg} / 100 \mathrm{~g})$. This difference may the different feeding types of various fish [26].

\section{Conclusion}

In general the Catfish are preferred and consumed by all the economic group of people and this are also considered as a low cost fish. This study revealed that this catfish species are able to compete with more commercially utilized species in terms of nutritional value, and they can definitely also compete when it comes to taste .

\section{Reference}

[1]. K Azam, and M. Y. Ali., "Biochemical Assessment on Selected Fresh Fish,” J. Bio Sci. Vol. 4, No. 1, 2004, pp. 9-10.

[2]. J. A Nettleton. "Seafood Nutrition in the 1990s," In: E. G. Bligh, Ed., Seafood Science and Technology, Fishing New Books, London, 1992, pp. 32-39.

[3]. F Shahidi, and J.R. Botta. Seafood: Chemistry, Processing Technology and quality, 1994, PP. 3-9. Chapman \& Hall, London.

[4]. S Ramakrishnan, and S. Venkatrao. Nurtitional Biochemistry. T.R. Publication, Chennai, 1995.

[5]. S.E.O Sadiku, and A.A. Oladimeji, 1991. Relationship of proximate composition of Latesniloticus(L), synodontisschallREs.Commun. 3 (1), 29- 40.

[6]. F Shahidi, andJ.R. Botta (1994) Seafood Chemistry, Processing Technology and quality Chapman \& Hall, London. PP. 3-9.

[7]. M Valverde, M.J. Periago, M. Santaella and G. Ros, the Content and Nutritional Significance of Minerals on Fish flesh in the presence and absence of bone, Food Chem.,71, 503-509 (2000).

[8]. E Nuray and O. Ozkan, Proximate Composition and Mineral Contents in Aqua Cultured Sea Bass (Dicentrarchuslabrax), Sea Bream (Sparusaurata) Analyzed by ICP-MS Food Chem., 102, 721-725 (2007).

[9]. Food and Nutrition Board, National Research Council Recommended Dietary Allowances, $10^{\text {th }}$ Edition, National academy press, Washington, DC (1989).

[10]. Y.Y Situ, Y.J. Sadovy. (2004) a preliminary study on local species diversity and seasonal composition in a Hong Kong wet market.

[11]. J Scandol, K. Rowling (2007) Resource assessments for multi-species fisheries in NSW, Australia: qualitative status determination using life history characteristics, empirical indicators and expert review. Wild Fisheries Program; Systems Research Branch Division of Science and Research; NSW Department of Primary Industries Cronulla Fisheries Centre; Cronulla NSW 2230. P., 15 Asian Fish Soc 17(3/4):235-248.

[12]. M Dubois, K.A. Gilles,J.K. Hamilton, P.A. Rebers, F. Smith (1956) Colorimetric method for determination of sugar and related substances. AnnalChem 28: 350.

[13]. O.H Lowry, N.J. Rosebrough, A.L. Farr and R.J. Randall, 1951. Protein measurement with the folin phenol reagent. J. Biol Chem., 193: 265-273.

[14]. J Folch, M. Lees, G.H. Sloane Stanley (1957) A simple method for the isolation and purification of total lipids from animal tissues. J. Biol Chem., 226: 497-509.

[15]. D.H Baker, Y. Han (1994) Ideal amino acid profile for chicks during the first three weeks posthatching. PoultSci 73: $1441-1447$.

[16]. E.G Bligh, W.J. Dyer (1959) A rapid method of total lipid extraction and purification. Can J BiochemPhysiol 37: 911-917.

[17]. AOAC, 1995 Official methods of analysis of AOAC International, 16th edn. AOAC International. Arlington, Va.,

[18]. S Sadasivam, and A. Manickam, (1996) Biochemical Methods. 2nd Edn. New Age International (P) Ltd., New Delhi. pp 179-186.

[19]. P.D Sethi (1997) Quantitative analysis of drugs in pharmaceutical formations (3rdedn) 589-590.

[20]. H.M Guzman, C.E. Jimenez (1992) Concentration of coral reefs by heavy metals along the carribean cost of central Africa (Costarica and Panama). Mar Pollut Bull 24: 554-561.

[21]. R Vignesh,andM. Srinivasan, 2012. Nutritional quality of processed head and bone flours of Tilapia (Oreochromismossambicus, Peters 1852) from Parangipettai estuary, South East Coast of India. Asian Pacific Journal of Tropical Biomedicine (2012) S368S372.

[22]. ManatChaijan.,AkkasitJongjareonrak, SuttirugPhatcharat, SoottawatBenjakul, SaroatRawdkuen. 2010. Chemical compositions and characteristics of farm raised giant catfish (Pangasianodongigas) muscle. LWT-Food Science and Technology 43 (2010) $452-457$.

[23]. OgbonnyaChukwu., 2009. Influence of drying methods on nutritional properties of Tillapia fish (Oreochromisnilotieus). World Journal of Agricultural Sciences. 5(2):256-258.

[24]. Fapohunda.,OlawumiOluwafunmilola and Ogunkoya, Marg. 2006. Effect of smoke-Drying on the proximate composition of TilapiaZillii, Parachannaobscura and Clariasgariepnius. Obtained from Akure, Ondo-State, Nigeria. Animal research international (2006) 3(2): 478-480.

[25]. K Holma, Ayinsa., and B.K. Maalekuu,(2013). Effect of traditional fish processing methods on the proximate composition of red fish stored under ambient room conditions. American Journal of Food and Nutrition. (2013).3.2.73.82.

[26]. R Kumaran, V. Ravi, B. Gunalan,S.Murugan, and A. Sundramanickam. 2012.Estimation of Proximate, amino acids, fatty acids and mineral composition of mullet (Mugilcephalus) of Parangipettai,South East Coast of India.Advance in Applied Science Research, 2012, 3(4):2015-2019.

[27]. OgbonnyaChukwu., and Ibrahim Mohmmed Shaba. 2009. Effects of drying methods on proximate composition of cat fish (Clariasgariepinus). World Journal of Agricultural Sciences. 5(1):114-116. 